\title{
Nutritional evaluation of dehulled faba bean (Vicia faba cv. Fiord) in feeds for weaner pigs
}

\author{
I.A. Emiola ${ }^{2}$ \& R.M. Gous ${ }^{1 \#}$ \\ ${ }^{1}$ Animal and Poultry Science, University of KwaZulu-Natal, P/B X01, Scottsville 3209, \\ Pietermaritzburg, South Africa \\ ${ }^{2}$ Ladoke Akintola University of Technology, Department of Animal Production and Health, \\ PMB 4000, 038, Ogbomoso, Nigeria
}

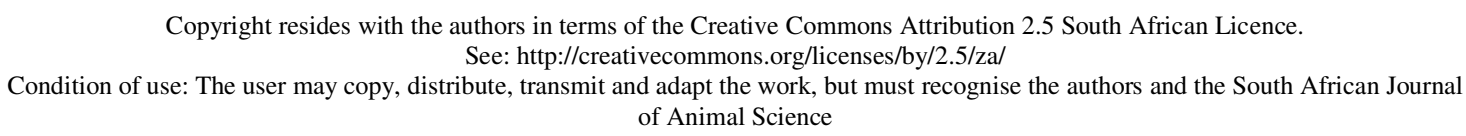

\begin{abstract}
The objective of this experiment was to determine whether faba bean could successfully be used in feeds for weaner pigs in the period 10 to $25 \mathrm{~kg}$ liveweight. An experiment was conducted using 48 weaner pigs (average weight $10 \pm 0.42 \mathrm{~kg}$ ) to determine the nutritive value of dehulled faba bean meal (Vicia faba cv. Fiord) in comparison with full-fat soy. Two basal feeds were formulated, the first containing no faba bean but with full-fat soy (FFS) as the protein source, while the second contained $300 \mathrm{~g}$ faba bean $/ \mathrm{kg}$ feed (FB). These feeds were blended to produce a series of five feeds (T1 to T5) containing a range of faba bean contents. In addition, a choice feeding treatment was included in the experiment to determine whether pigs showed preferences for or against faba bean. The experimental feeds were: 1) $1.0 \mathrm{FFS}$; 2) $0.75 \mathrm{FFS}+0.25$ FB; 3) 0.5 FFS + 0.5 FB; 4) 0.25 FFS + 0.75FB; 5) $1.0 \mathrm{FB}$ and 6) choice between FFS and FB. Feeds were formulated to meet or exceed NRC (1998) nutrient requirements of weaner pigs. Diluting full-fat soya with dehulled faba bean meal had no effect on growth rate (ADG), feed intake (ADFI), feed conversion efficiency (FCE) or time taken to attain final weight. Male pigs had a numerically higher ADFI (1150 vs. $992 \mathrm{~g} / \mathrm{d})$ and ADG (553 vs. $539 \mathrm{~g} / \mathrm{d}$ ) than females, and reached the final liveweight on average $3 \mathrm{~d}$ before the females. When given a choice between the two basal feeds, no preference was shown for either feed. It may be concluded that a feed for weaner pigs may contain as much as $300 \mathrm{~g}$ dehulled faba bean $/ \mathrm{kg}$ without causing any deleterious effects on performance as long as the quality of the faba beans is the same as that used in this trial.
\end{abstract}

Keywords: Anti-nutritional factors, protein sources, growth response

\# Corresponding author: gous@ukzn.ac.za

\section{Introduction}

Faba beans (Vicia faba) may be considered a potential source of protein and energy in pig feeds, being rich in both and with an amino acid content similar to that of soybean except for a lower level of methionine (Bond et al., 1985). However, the use of faba bean as an alternative energy and protein source in growing pig feeds has produced contradictory results due to the level of inclusion in the feeds and the presence in some cases of anti-nutritional factors, most especially tannins (Marquardt et al., 1974; Abbey et al., 1979; Moseley \& Griffiths, 1979; Brand et al., 1995). It has been reported that growth of pigs given feeds containing faba bean is less than that predicted from its chemical composition (Aherne et al., 1977). The discrepancy becomes more apparent when inclusion rates exceed 0.15 in the feed while at 0.40 severe reduction in performance has been observed (Fowler, 1980), although in the trial conducted by Brand et al. (1995) performance was not reduced when faba beans were included at 0.2 of the diet. Where performance has been reduced by the inclusion of faba beans this has been attributed to the content of condensed tannins and nonstarch polysaccharides (NSP) in the seeds. The testa of the majority of the commonly grown commercial varieties of faba bean is known to contain appreciable amounts of condensed tannins (proanthocyanidins)

URL: http://www.sasas.co.za

ISSN 0375-1589 (print), ISSN 222-4062 (online)

Publisher: South African Society for Animal Science 
and the significance of these polyphenolic compounds in reducing the nutritive value of faba bean seeds for monogastric animals has been clearly established (Reddy et al., 1985; Marquardt, 1989). The inclusion of high amounts of faba bean in feeds has been reported also to have detrimental effects on the performance of rats (Marquardt et al., 1974; Abbey et al., 1979) and chickens (Guillaume, 1977, Rubio et al., 1990). These effects are associated with an astringent taste as well as with the ability of condensed tannins to form complexes with digestible dietary proteins, with enzymes or with both (Wiseman \& Cole, 1988). However, it should be recognized that the astringent taste and reduced acceptability associated with high levels of tannins will be diluted, depending on the level of inclusion of faba bean in the formulated feeds.

Marquardt et al. (1973) reported that most of the anti-nutritional factors found in the beans are located in the dehulled cotyledon, which led them to recommend dehulling and heat-treating the bean for optimum efficiency of faba bean utilization. Jansman et al. (1995) and Knox et al. (1995) also indicated that the poorer digestibility of the starch from coloured-flowered varieties of faba bean is due to the higher proanthocyanidin (condensed tannin) content of the hulls of these varieties compared with the white-flowered varieties.

The variety of faba beans used in this trial was the same as that used in the trials of Brand et al. (1995) and Perez-Maldonado et al. (1999), and is the only variety grown commercially in South Africa. Brand et al. (1995) determined the alkaloid content of the beans using the method described by Ruiz (1977) and found no trace of any alkaloids in the seed. However, they did find that the beans contained tannin $(0.48 \%)$. Similarly, Perez-Maldonado et al. (1999) measured the condensed tannin content using the method described by Perez-Maldonado \& Norton (1996) and found a total of 15.1 Desmodium intortum equivalents. They did not specify whether they tested hulled or dehulled beans but it is presumed that hulls were present.

In a previous growth trial (Harding \& Gous, 2006, unpublished) to evaluate dehulled faba beans as a protein and energy source for growing pigs between 25 and $85 \mathrm{~kg}$ liveweight, it was observed that an inclusion level of $200 \mathrm{~g}$ faba bean $/ \mathrm{kg}$ feed supported the same rate of growth as that of a soya-based feed. Where a choice was offered between feeds containing soya and faba bean the pigs consumed the same amount of each feed, suggesting that the levels of tannins and other anti-nutritional factors (ANFs) in the variety tested were sufficiently low not to influence its acceptability as a protein source.

In previous trials in which faba beans have been evaluated as a protein source for pigs, other than that by Harding \& Gous (2006), only one concentration of faba beans has been used, this usually being around $200 \mathrm{~g}$ faba beans $/ \mathrm{kg}$ feed. An important question is whether the responses in food intake, growth or feed efficiency would change as the concentration of faba beans in the feed was increased. The objective of this study was to measure the response of weaner pigs between 10 and $25 \mathrm{~kg}$ liveweight to increasing concentrations of dehulled faba bean, up to a maximum of $300 \mathrm{~g} / \mathrm{kg}$, and to determine whether the piglets would avoid this protein source when given a choice between a feed with $300 \mathrm{~g}$ faba beans $/ \mathrm{kg}$ and another without this protein source.

\section{Materials and Methods}

The dehulled faba beans (Vicia faba L.) used in this trial were sourced from the Department of Agriculture, Cedara, in Pietermaritzburg, KwaZulu-Natal Province, South Africa. A dose response trial was designed, with a further choice-feeding treatment added. Two basal feeds (Table 1) were formulated, one without faba bean meal (containing $300 \mathrm{~g}$ full fat soya/kg feed) (FFS) and the second containing $300 \mathrm{~g}$ dehulled faba bean meal/kg (FB). These two basal feeds were blended in appropriate proportions to produce a series of five feeds (Treatments 1 to 5) containing a range of faba bean contents. The experimental feeds were: 1) $1.0 \mathrm{FFS}$ ); 2) $0.75 \mathrm{FFS}+0.25 \mathrm{FB}$; 3) 0.5 FFS + 0.5 FB; 4) 0.25FFS + 0.75 FB; 5) $1.0 \mathrm{FB}$; and 6) a choice between FFS and FB. Feeds were formulated to meet or exceed the NRC (1998) nutrient requirement of growing pigs. All feeds were made available ad libitum and fed in mash form.

The 48 commercial Large White $\mathrm{x}$ Landrace pigs used in this experiment were purchased from a commercial farm near the project site. The pigs were fed a commercial weaner feed until the mean weight of all pigs was $10 \pm 0.42$ (mean $\pm \mathrm{SD}$ ) $\mathrm{kg}$, when they were placed on the experimental feeds. The pigs were ranked according to body weight within a sex, and pigs within each weight category of six were then randomly allocated to one of the six treatments. Four males and four females were allocated to each dietary treatment and each pig was housed individually.

Each pen $\left(1.92 \mathrm{~m}^{2}\right)$ was equipped with a nipple drinker and two hardened plastic self-feeder bins (Big Dutchman). Animals were allowed free and continuous access to food and water. Each pig was weighed weekly, the amount of feed in the bins was checked daily and any feed required was weighed in and 
recorded. On reaching $25 \mathrm{~kg}$ liveweight each pig was removed from the trial and the food remaining was weighed. Average daily live weight gain (ADG) for each pig was determined by fitting a linear regression to the weights recorded over time. Mean daily feed intake was calculated as the difference between feed input over the whole experiment and that remaining at the end divided by the time taken to reach the final liveweight.

Table 1 Composition $(\mathrm{g} / \mathrm{kg})$ of the basal feeds

\begin{tabular}{lcc}
\hline Ingredient & $\begin{array}{c}\text { Full fat soya (FFS) } \\
\text { basal }\end{array}$ & $\begin{array}{c}\text { Faba bean (FB) } \\
\text { basal }\end{array}$ \\
\hline Maize & 307 & 360 \\
Wheat bran & 243 & \\
Soybean full fat & 300 & \\
Faba bean meal - dehulled & & 300 \\
Soybean meal 480 g CP/kg & 103 & 274 \\
L-Lysine HCl & 2.3 & \\
DL Methionine & 2.1 & 2.2 \\
L-Threonine & 1.4 & 0.6 \\
Vit+min premix & 1.5 & 1.5 \\
Limestone & 19.4 & 19.2 \\
Monocalcium phosphate & 17.5 & 19.2 \\
Salt & 2.7 & 2.8 \\
Sodium bicarbonate & 0.5 & 0.3 \\
Oil - sunflower & & 20.3 \\
Total & 1000 & 1000
\end{tabular}

$\begin{array}{lcc}\text { Calculated nutrient composition }(\mathrm{g} / \mathrm{kg}) & & \\ \text { Digestible energy }(\mathrm{MJ} / \mathrm{kg}) & 13.80 & 228 \\ \text { Crude protein } & 224 & 47.1 \\ \text { Crude fibre } & 52.7 & 4.8 \\ \text { Methionine } & 4.8 & 12.1 \\ \text { Lysine } & 12.0 & 9.5 \\ \text { Threonine } & 9.8 & 7.8 \\ \text { Methionine + cysteine } & 7.8 & 11.0 \\ \text { Calcium } & 11.0 & 9.4 \\ \text { Total phosphorus } & 9.4 & 5.0 \\ \text { Available phosphorus } & 5.0 & \end{array}$

Vit+min premix contained per kg feed: $12000 \mathrm{IU}$ vitamin $\mathrm{A} ; 200 \mathrm{IU}$ vitamin $\mathrm{D}_{3} ; 1.5 \mathrm{mg}$ vitamin $\mathrm{B}_{1} ; 5 \mathrm{mg}$ vitamin $\mathrm{B}_{2}$; $4 \mathrm{mg}$ vitamin $\mathrm{B}_{6} ; 1 \mathrm{mg}$ folic acid; $50 \mu \mathrm{g}$ vitamin $\mathrm{B}_{12} ; 50 \mathrm{mg}$ vitamin $\mathrm{E} ; 350 \mathrm{mg}$ choline chloride; $40 \mathrm{mg}$ niacin; $20 \mathrm{mg}$ Ca panthothenate; $3 \mathrm{mg}$ vitamin $\mathrm{K} ; 100 \mu \mathrm{g}$ biotin; $500 \mu \mathrm{g}$ cobalt; $2 \mathrm{mg}$ iodine; $300 \mu \mathrm{g}$ selenium; $10 \mathrm{mg}$ manganese; $6.5 \mathrm{mg}$ copper; $120 \mathrm{mg}$ zinc; $100 \mathrm{mg}$ iron; $125 \mathrm{mg}$ antioxidant.

Because the first five dietary treatments constituted a response series, with increasing faba bean contents, these treatments were analysed by regression using a second order term initially, but where this was not significant, a linear regression was used. To test whether the choice made by pigs on treatment 6 differed from 0.5 (no choice) a one sample Student t-test was used. Genstat (2005) was the statistical package used for these analyses. 
All chemical analyses on the ingredients and the feeds were performed in duplicate. The two basal feeds along with a sample of the dehulled faba bean meal used were finely ground to pass through a 1-mm screen before chemical analysis. Feeds and faba bean meal samples were analyzed for dry matter (DM), gross energy (GE), neutral detergent fibre (NDF) and crude protein (CP). DM and NDF were determined according to the AOAC (1990) procedures. The faba bean meal was further analysed for the presence of condensed tannins, which were quantified using the vanillin-sulphuric acid assay method of Kuhla \& Ebmeier (1981), modified by using catechin instead of phloroglucinol as a reference compound. Briefly, 200 $\mathrm{mg}$ of faba bean (sieve mill $1.0 \mathrm{~mm}$ ) was extracted in $30 \mathrm{~mL}$ of dimethylformamide ( 0.8 in water) containing $0.01 \mathrm{M}$ sodium sulphite under reflux conditions for 30 minutes. Aliquots of $0.5 \mathrm{~mL}$, containing $\mathrm{ca} .10 \mu \mathrm{g}$ equivalents of condensed tannin were incubated for 20 minutes at room temperature in $0.2 \%$ vanillin/70\% sulphuric acid (w/w) before absorption measurement at $500 \mathrm{~nm} . \mathrm{CP}(\mathrm{N}$ x 6.25) content was determined using a LECO NS 2000 Nitrogen Analyzer (LECO Corporation, St. Joseph, MI). GE was measured using a Parr adiabatic bomb calorimeter (Parr Instrument Co., Moline, IL).

\section{Results}

The analysed GE, CP and NDF contents of the two basal feeds and the faba beans used in the trial are shown in Table 2. The digestible energy (DE) content of the two feeds was calculated from the GE and NDF using the equation of Whittemore (1998). The condensed tannin content in the faba beans was <0.5\% catechin equivalents (Table 2).

Table 2 Analysed nutrient composition (as is basis) of basal feeds and faba bean ( $\mathrm{g} / \mathrm{kg}$ )

\begin{tabular}{lccc}
\hline \multicolumn{1}{c}{ Analyses } & $\begin{array}{c}\text { Basal } \\
\text { no faba bean }\end{array}$ & $\begin{array}{c}\text { Basal } \\
\text { with faba bean }\end{array}$ & $\begin{array}{c}\text { Faba bean } \\
\text { meal }\end{array}$ \\
\hline Crude protein & 228 & 224 & 236 \\
$\mathrm{GE}^{1}(\mathrm{MJ} / \mathrm{kg})$ & 16.98 & 15.96 & 15.42 \\
$\mathrm{DE}^{2}(\mathrm{MJ} / \mathrm{kg})^{1}$ & 13.05 & 13.36 & 12.17 \\
$\mathrm{NDF}^{3}$ & 182 & 125 & 166 \\
Tannin $(\%)^{4}$ & - & & $<0.5$ \\
\hline
\end{tabular}

1 Gross energy.

2 Digestible energy $=3.77-(0.19 \times \mathrm{NDF})+(0.75 \times \mathrm{GE}) \quad$ (Whittemore, 1998).

3 Neutral detergent fibre.

${ }^{4}$ Catechin equivalents.

Throughout the duration of this experiment the pigs remained healthy, and readily consumed the experimental feeds offered. Male pigs had a numerically higher average daily feed intake (ADFI) (1150 vs. $992 \mathrm{~g} / \mathrm{d})$ and average daily gain (ADG) $(553$ vs. $539 \mathrm{~g} / \mathrm{d})$ than female pigs. Although the magnitude of responses differed between males and females, no significant interactions existed between sex and dietary treatment, so the means for the two sexes were pooled. These pooled means, for ADG, ADFI, feed conversion efficiency (FCE) ( $\mathrm{g}$ gain $/ \mathrm{kg}$ feed) and time to reach the final liveweight are presented in Table 3 for the six dietary treatments imposed. There were no differences in ADG, ADFI, FCE or time taken to reach final liveweight among the dietary treatments, nor were the regressions of these variables (Treatments 1 to 5) against faba bean inclusion significantly different from zero (Table 4). A quadratic term was included in the regression model initially, but in no case was this significant, hence it was dropped and only the linear term fitted.

In the treatment in which pigs were offered a choice between the soya and faba bean basal feeds the proportion of faba basal chosen was $0.436 \pm 0.10$, which proved to be not significantly different from 0.5 $(P>0.5)$, indicating that the pigs showed no preference for either of the two basal feeds. 


\section{Discussion}

The acceptability of dehulled faba beans as a replacement for full fat soybeans in weaner pig feeds was investigated in this study. Of interest was whether a significant trend in performance would be evident as a result of the changing proportions of soya and faba beans in the experimental feeds, and whether the pigs would choose one of the basal feeds in preference to the other. The results suggest that the nutritional quality of the two basal feeds was sufficiently similar in all respects such that performance was the same on all experimental feeds, and neither of the feeds was chosen in preference to the other.

The DE value used for faba beans in the formulation of the faba bean basal feed was identical to the analysed value $(12.2 \mathrm{MJ} / \mathrm{kg})$. However, the DE of the two basal feeds used in the trial differed one from the other and from the calculated values, although this had no apparent influence on the result. The NDF content $(166 \mathrm{~g} / \mathrm{kg})$ and crude protein of the seeds $(236 \mathrm{~g} / \mathrm{kg})$ measured in this trial are in good agreement with the values reported by other authors (Chavan et al., 1989; Hulse 1994). The chemical composition of faba bean is similar in most respects to that of soybean meal, the most important exception being the content of condensed tannins (Van der Poel et al., 1992). The condensed tannin content of the faba beans used in this trial was low $(<0.5 \%$ catechin equivalents). For some perspective on the variation possible in tannin content of faba beans, Jansman et al. (1994) compared two sources of faba bean hulls in which the condensed tannin contents varied from $<0.1 \%$ (LT) to $3.5 \%$ (HT) catechin equivalents. They found that the apparent ileal digestibility of crude protein $(\mathrm{N} \times 6.25)$ was lower for the HT than for the LT diet $(0.614 v .0 .728 ; P<0.05)$ and argued that condensed tannins are probably responsible for the lower activity of trypsin in ileal digesta of pigs fed high-tannin faba bean hulls. In the present trial the hulls were excluded and the resultant tannin content was sufficiently low to have no effect on the performance of the weaner pigs.

Table 3 Main effects of feed and sex on average daily gain (ADG), food intake (ADFI), food conversion efficiency (FCE) (g gain/kg feed) of pigs between 10 and $25 \mathrm{~kg}$ live weight, and the time taken (d) to reach the final weight

\begin{tabular}{lcccc}
\hline Main Effect & $\begin{array}{c}\text { ADG } \\
(\mathrm{g} / \mathrm{d})\end{array}$ & $\begin{array}{c}\text { ADFI } \\
(\mathrm{g} / \mathrm{d})\end{array}$ & $\begin{array}{c}\text { FCE } \\
(\mathrm{g} / \mathrm{kg})\end{array}$ & $\begin{array}{c}\text { Duration } \\
(\mathrm{d})\end{array}$ \\
\hline Feed & & & & \\
1 & 561 & 1029 & 522 & 27.9 \\
2 & 470 & 1137 & 431 & 28.5 \\
3 & 542 & 997 & 537 & 30.0 \\
4 & 620 & 1100 & 560 & 27.0 \\
5 & 561 & 1086 & 567 & 26.0 \\
6 (FFS vs. FB) & 521 & 1075 & 490 & 28.4 \\
Sex & & & & \\
$\quad$ Male & 553 & 1150 & 495 & 26.5 \\
$\quad$ Female & 539 & 992 & 541 & 29.5 \\
RMS $^{1}$ (33 d.f.) & 16719 & 55128 & 17974 & 35.9 \\
T & & & &
\end{tabular}

Residual mean square.

Nutritive value of legumes is influenced by species, source, level of inclusion in the feed, content of anti-nutritional factor and the methods of storage and processing (Gupta, 1987). Low nutritive value of faba beans (Vicia faba) can be partly due to resistance of the bean storage proteins towards hydrolysis by digestive proteolysis enzymes such as pepsin and pancreatin (Liener \& Thompson, 1980; Savelkoul et al., 1992). The presence of tannin in the gastro-intestinal tract may induce complexes with dietary protein or digestive enzymes, or both, thereby reducing the digestibility of the protein (Marquardt, 1989). The increasing additions of faba bean meal at the expense of full fat soybean did not affect the performance of 
Table 4 Regression coefficients relating average daily gain (ADG, g/d), average daily feed intake (ADFI, $\mathrm{g} / \mathrm{d}$ ), feed conversion efficiency (FCE, g gain/ $\mathrm{kg}$ feed) and time taken to reach $25 \mathrm{~kg}$ liveweight (d), to increasing amounts of faba bean inclusion in the feed of weaner pigs between 10 and $25 \mathrm{~kg}$ live weight

\begin{tabular}{lccc}
\hline & \multicolumn{2}{c}{ Regression coefficient \pm SE } & Significance \\
\hline ADFI & 0.170 & 0.595 & N.S. \\
ADG & 0.703 & 0.595 & N.S. \\
FCE & 1.057 & 0.633 & N.S. \\
Time taken & -0.019 & 0.028 & N.S. \\
\hline
\end{tabular}

pigs in this trial. Whereas some authors (Ahmed et al., 1991; Van der Poel et al., 1992) have reported a decrease in food intake and hence performance with an increase in faba bean content, others, such as Gupta \& Haslam (1980), suggested that the slightly astringent taste of condensed tannins increases palatability and stimulates food intake. Also faba beans contain oligosaccharides, mainly stachyose, raffinose and verbascose, which in turn contain glucose and galactose residues that can persist in sugar metabolism pathways in the digestive tract; according to Williams et al. (1988) this results in fermentation and increased production of methane and other gases, causing discomfort and abdominal pain. Where the content of these anti-nutritional factors is high, usually when hulls are not removed, it is more likely that performance will be reduced, as was the case reported by Fowler (1980). Clearly, the higher the inclusion of such faba beans in complete feeds, the more severe the depression in performance. It is for this reason that a response trial is useful, as performance could be improved at low faba bean concentrations but increasingly reduced as the inclusion level is increased. In the present trial there was no such change in performance, as evidenced by the horizontal slope of the regressions reflecting the effect of increasing faba bean contents on performance. This lack of response confirms that the faba beans used here were of a high quality.

If it can be assumed that appetite is a measure of the success (or failure) of an animal to attain sufficient of the essential nutrients required to grow to its genetic potential at the lowest physiological cost, then animals, when given a choice between feeds, will choose a combination that will maximize growth and minimize adverse metabolic reactions (Kyriazakis, 1997). Therefore, measuring the preference made by pigs given a choice between the two basal feeds is a reliable method of identifying the presence of antinutritional factors. As the pigs showed no preference for the soybean basal, it may be assumed that if antinutritional factors were present in the dehulled faba beans used in this study the content was below that detectable by, or of consequence to, pigs.

\section{Conclusion}

The quality of faba beans used in this trial was such that pigs performed as well on this source of protein as they did on the soybean basal feed, and when offered a choice between the two basal feeds, showed no preference for one or the other. Consequently, a feed for weaner pigs may contain as much as $300 \mathrm{~g}$ dehulled faba bean meal $/ \mathrm{kg}$ without causing any deleterious effects on performance as long as the quality of the faba beans is the same as that used in this trial. Where faba bean varieties with a high condensed tannin or oligosaccharide content are used, it would be unlikely that weaner performance would be unaffected. There are areas of South Africa where this protein source can be grown more successfully than can soybeans, and to avoid the high cost of transporting soybeans to these areas, there would be an advantage in cultivating faba beans and using them in place of soybeans for pig production.

\section{Acknowledgements}

The authors wish to thank Wiseman Manqele, Ann Kinsey and Debbie Davies for their technical assistance. This work was supported by a grant from the Protein Research Foundation. 


\section{References}

Abbey, B.W., Neale, R.J. \& Norton, G., 1979. Nutritional effects of field bean (Vicia faba) proteinase inhibitors fed to rats. Br. J. Nutr. 4, 34-38.

Aherne, F.X., Lewis, A.J. \& Hardin, R.T., 1977. An evaluation of faba bean (Vicia faba) as a protein supplement for swine. Can. J. Anim. Sci. 57, 321-326.

A.O.A.C., 1990. Official Methods of Analysis. $15^{\text {th }}$ Ed. Assoc. Offic. Anal. Chem., Washington, D.C., USA.

Bond, D.A., Lawes, D.A., Hawtin, G.C., Saxena, M.C. \& Stephens, J.S., 1985. Faba bean (Vicia faba L.). In: Grain Legume Crops. Eds Summerfield, R.J. \& Roberts, E.H., William Collins \& Sons, London, U.K. pp. 199-265.

Brand, T.S., Olckers, R.C. \& Van der Merwe, J.P., 1995. Evaluation of faba beans (Vicia faba cv. Fiord) and sweet lupins (Lupinus albus cv. Kiev) as protein sources for growing pigs. S. Afr. J. Anim. Sci. 25, 31-35.

Chavan, J.K., Kute, L.S. \& Kadam, S.S., 1989. In: CRC Handbook of World Legumes. Eds Salunkhe, D.D. \& Kadam, S.S., CRC Press, Boca Raton, Florida, USA. pp. 223-245.

EFG Software, 2005. www.efgsoftware.net (accessed January 2006).

Fowler, V.F., 1980. The value of field beans (Vicia faba L.) and other legumes for the feeding of pigs. In: Vicia faba: Feeding value, Processing and Viruses. Ed. Bond, D.A., Martinus Nijhoff, The Hague. pp. $31-41$

GenStat, 2005. Genstat Statistical Software, Release $8^{\text {th }}$ Ed. Genstat Executable, Lawes Agricultural Trust.

Guillaume, J., 1977. Use of field bean (Vicia faba L.) and peas (Pisum sativum) in laying hen and growing chicken diets, In: Protein Quality from Legume Crops. Ed. Commission of European Communities. Brussels. Luxembourg, (ECSC-EEC-CAEC). pp. 217-231.

Gupta, Y.P., 1987. Anti-nutritional and toxic factors in food legumes: A review. Qual. Plant. Plant Foods Hum. Nutr. 37, 201-208.

Hulse, J.H., 1994. Nature, composition and utilization of food legumes. In: Expanding the Production and Use of Cool Season Food Legumes. Eds Muehlbauer, F.J. \& Kaiser, W.J., Kluwer Academic Publishers, Dordrecht, The Netherlands. pp. 77-97.

Jansman, A.J.M., Enting, H., Verstegen, M.W.A. \& Huisman, J., 1994. Effect of condensed tannins in hulls of faba beans (Vicia faba L.) on the activities of trypsin (EC 2.4.21.4) and chymotrypsin (EC 2.4.21.1) in digesta collected from the small intestine of pigs. Br. J. Nutr. 71, 627-641.

Kuhla, S. \& Ebmeier, C., 1981. Untersuchungen zum Tanningehalt in Ackerbohnen (Research into the levels of tannins in faba beans) Archiv. fur Tierer. 31, 573-588.

Kyriazakis, I., 1997. The nutritional choices of farm animals: to eat or what to eat? In: Animal Choices, British Society of Animal Production Occasional Publication No. 20. Eds Forbes, J.M., Lawrence T.L.J., Rodway, R.G. \& Varley, M.A., Edinburgh. pp. 55-65.

Liener, I.E., 1989. Anti-nutritional factors. In: Legumes: Chemistry, Technology and Human Nutrition. Ed. Matthews, R.H., Marcel Dekker Inc., New York, USA. pp. 340-366.

Liener, I.E. \& Thompson, R.M., 1980. In vitro and in vivo studies on the digestibility of the major storage protein of the navy bean (Phaseolus vulgaris). Qual. Plant. Plant Foods Hum. Nutr. 30, 13-25.

Marquardt, R.R., 1989. Dietary effects of tannins, vicine and convicine. In: Recent Advances of Research in Anti-nutritional Factors in Legume Seeds. Eds Huisman, J., Van der Poel, A.F.B. \& Liener, I.E., Pudoc, Wageningen, The Netherlands. pp.141-155.

Moseley, G. \& Griffiths, D.W., 1979. Varietal variation in antinutritive effect of field bean (Vicia Faba) when fed to rats. J. Sci. Fd. Agric. 30, 772-778.

Reddy, N.R., Pierson, M.D., Sathe, S.K. \& Salunkhe, D.K., 1985. Dry bean tannins: A review of nutritional implications. J. Am. Chem. Soc. 62, 541-549.

Rubio, L.A., Brenes, A. \& Castano, M., 1990. The utilization of raw and autoclaved faba bean (Vicia faba L. var. minor) and faba bean fractions in diets for growing broiler chickens. Br. J. Nutr. 63, 419-430.

Ruiz, L.P., 1977. A rapid screening test for lupin alkaloids. N. Z. J. Agric. Res. 20,51.

Savage, G.P., 1988. Antinutritive factors in peas. In: Recent Advances of Research in Anti-nutritional Factors in Legume Seeds. Eds Huisman, J., Van der Poel, A.F.B. \& Liener, I.E., Pudoc, Wageningen, The Netherlands. pp. 342-349. 
Savelkoul, F.H.M.G., Tamminga, S., Kampert, G.J. \& Leenaars, P.P.A.M., 1992. The degradation of lectins and phaseolin in white kidney beans (Phaseolus vulgari L.) during germination and in vitro enzymatic hydrolysis. Proc. Interlectin $13^{\text {th }}$ Congr., Berlin, Germany. p. 13.

Van der Poel, A.F.B., Dellaert, L.M.W., Van Norel, A. \& Helsper, J.P.F.G., 1992. The digestibility of faba bean (Vicia faba) as affected by breeding towards the absence of condensed tannins. Br. J. Nutr. 68, 793-800.

Williams, P.C., Bhatty, R.S., Deshapande, S.S., Hussein, L.A. \& Savage, G.P., 1988. Improving nutritional quality of cool season food legumes. In: World Crops: Cool Season Food Legumes. Ed. Summerfield, R.J., Kluwer Academic Publishers, Dordrecht, The Netherlands. pp. 113-129.

Wiseman, J. \& Cole, D.J.A., 1988. European legumes in diets for non-ruminants. In: Recent Advances in Animal Nutrition. Eds Haresign, W. \& Cole, D.J.A., Nottingham University Press. pp. 13-37. 